\title{
Interface Synthesis of $\mathrm{FePO}_{4}$ with Different Morphologies and Effect of Morphology on the Electrochemical Performance of $\mathrm{LiFePO}_{4} / \mathrm{C}$
}

DOI: $10.15255 /$ KUI.2015.017 KUI-24/2015

Preliminary communication Received March 17, 2015 Accepted May 23, 2015

\author{
Y.-H. Luo, a, b, ${ }^{*}$ N. He, ${ }^{\mathrm{c}^{*}}$ Y.-C. Wang, ${ }^{\mathrm{b},{ }^{* * *}}$ W.-G. Cao, ${ }^{\mathrm{a},{ }^{* * * *}}$ and P. Feng ${ }^{\mathrm{a}, \mathrm{d},{ }^{* * * * *}}$ \\ a School of Chemical Engineering; Nanjing University of Science and Technology \\ Jiangsu, 210094 Nanjing, PR China \\ b Sinosteel Anhui Tianyuan Technology Co., Ltd., 243000 Anhui Maanshan, PR China \\ 'Sinosteel Maanshan Institute of Mining Research Co., Ltd., Maanshan, \\ 243000 Anhui, PR China \\ ${ }^{d}$ National Quality Supervision and Inspection Center for Industrial Explosive Materials \\ Jiangsu, 210094 Nanjing, PR China
}

\begin{abstract}
\| Abstract
In our work, interface synthesis method was put forward to prepare $\mathrm{FePO}_{4}$ with different morphologies, and the effect of morphology on the preparation and electrochemical performance of $\mathrm{LiFePO}_{4} / \mathrm{C}$ was investigated. The results showed that the morphology of $\mathrm{FePO}_{4}$ was amorphous and monoclinic at the treatment temperatures of $30{ }^{\circ} \mathrm{C}$ and $80^{\circ} \mathrm{C}$, respectively. $\mathrm{LiFePO}_{4} / \mathrm{C}$ prepared from two crystal precursors were both hemispherical hollow with an olivine crystal structure. $\mathrm{LiFePO}_{4} / \mathrm{C}$ produced from the monoclinic structured precursor exhibited smaller-sized morphology and better electrochemical performance, and its discharge capacities were $155.9 \mathrm{~mA} \mathrm{~h} \mathrm{\textrm {g } ^ { - 1 }}$ and $141.8 \mathrm{~mA} \mathrm{~h} \mathrm{~g}^{-1}$ at the rates of $0.1 \mathrm{C}$ and $1 \mathrm{C}$, respectively. After 150 cycles, its capacity retention was about $97.8 \%$ and $95.1 \%$ at $0.1 \mathrm{C}$ and $1 \mathrm{C}$, respectively.

$\|$ Keywords
\end{abstract}

$\mathrm{FePO}_{4}, \mathrm{LiFePO}_{4} / \mathrm{C}$, lithium-ion battery, composite materials, energy storage and conversion

\section{Introduction}

Since $\mathrm{LiFePO}_{4}$ was reported as a cathode material for lithium-ion battery by Goodenough in the 1990s, ${ }^{1}$ it has been considered as a promising cathode material for Li-ion battery due to its advantages, such as low cost, no toxicity, high thermal stability, a relatively high theoretical capacity of $170 \mathrm{~mA} \mathrm{~h} \mathrm{~g}{ }^{-1}$ and excellent cycling performance. ${ }^{2-5}$ $\mathrm{LiFePO}_{4} / \mathrm{C}$ composite has been successfully put into practice by carbon coating, which is a good solution to enhance the conductivity of pristine $\mathrm{LiFePO}_{4} \cdot{ }^{6-8}$ Aiming to improve the electrochemical properties, different precursors, such as $\mathrm{FePO}_{4}, \mathrm{Fe}_{2} \mathrm{O}_{3}, \mathrm{FeC}_{2} \mathrm{O}_{4}$ have been used as precursors to prepare $\mathrm{LiFePO}_{4} / \mathrm{C}$ composite. Among them, $\mathrm{FePO}_{4}$ has attracted much more attention as a good precursor, and different methods have been studied to synthesize $\mathrm{FePO}_{4} \cdot{ }^{9-13}$ These methods, however, commonly involve complicated synthetic routes and high synthetic costs. In addition, there are few reports about the effect of the crystal style of $\mathrm{FePO}_{4}$ on the preparation and electrochemical performance of $\mathrm{LiFePO}_{4} / \mathrm{C}$ composite.

Herein, we report an interface synthesis method to prepare $\mathrm{FePO}_{4}$ with different crystal types, and the effect of crystal type on the electrochemical performance of $\mathrm{LiFePO}_{4} / \mathrm{C}$ composite was investigated.

\footnotetext{
*Corresponding author: Yan-Hua Luo, e-mail: 354255308@qq.com

**Nan He, e-mail: masbaowei@163.com

${ }^{* * *}$ Yi-Cun Wang, e-mail: 95236300@qq.com

****Wei-Guo Cao, e-mail: 78300136@qq.com

***** Pan Feng, e-mail: iempf@163.com
}

\section{Experiment}

$\mathrm{FePO}_{4}$ precursor was prepared using low-cost $\mathrm{FeSO}_{4}$ and $\mathrm{H}_{3} \mathrm{PO}_{4}$ as raw materials. $200 \mathrm{~mL}$ of a water solution of $\mathrm{FeSO}_{4}, \mathrm{C}\left(\mathrm{FeSO}_{4}\right)=0.13 \mathrm{~mol} \mathrm{~L}^{-1}$, and $9 \mathrm{~mL}$ of $\mathrm{H}_{3} \mathrm{PO}_{4}$, $w\left(\mathrm{H}_{3} \mathrm{PO}_{4}\right)=85 \%$, were mixed together in the reaction still, stirred for $1 \mathrm{~h}$, then $200 \mathrm{~mL}$ of ethanol were added into the solution under vigorous stirring for $3 \mathrm{~h}$. Subsequently, the temperature of the slurry was kept at $30{ }^{\circ} \mathrm{C}$ and $80^{\circ} \mathrm{C}$ for $5 \mathrm{~h}$, respectively, filtrated, washed and dried. The precursor prepared at $30{ }^{\circ} \mathrm{C}$ was labelled as S1, the precursor prepared at $80{ }^{\circ} \mathrm{C}$ was labelled as S2. Then, the as-prepared precursor and $\mathrm{LiOH} \mathrm{H}_{2} \mathrm{O}$ were mixed in a mill. Simultaneously, a proper amount of glucose $\left(\mathrm{C}_{6} \mathrm{H}_{12} \mathrm{O}_{6}\right)$ was added into the mixture as carbon source. After drying treatment, the mixture was calcined at $650{ }^{\circ} \mathrm{C}$ for $12 \mathrm{~h}$ and cooled down under $\mathrm{N}_{2}$ atmosphere. Finally, the $\mathrm{LiFePO}_{4} / \mathrm{C}$ composite samples were obtained. They were labelled as L1 (prepared from S1), and L2 (prepared from S2), respectively.

The crystalline phases of synthesized $\mathrm{FePO}_{4}$ precursor and $\mathrm{LiFePO}_{4} / \mathrm{C}$ composite were identified with $\mathrm{X}$-ray diffraction (XRD, X'Pert Pro MPD, Cu K $\alpha$ radiation, $\lambda=1.54178 \AA$ ). The particle morphologies and sizes of the samples were examined by field-emission scanning electron microscopy (FE-SEM, SIRION). The Brunauer-Emmett-Teller (BET) specific surface area of as-synthesized samples was determined by using an instrument of ASAP2020. The elemental result was analysed by $\mathrm{X}$-ray fluorescence spectrometer (Axios). 
The electrochemical performances were investigated in CR2025 coin-type lithium half-cells. NMP was employed as the solvent, blended slurry consisting of active material, acetylene black and PVDF binder in a weight ratio of $75: 15: 10$ were coated on $\mathrm{Al}$ sheet $(\phi=12 \mathrm{~mm})$ and dried at $110^{\circ} \mathrm{C}$ in a vacuum for 12 hours. Lithium foil served as the reference and counter electrode, and Celgard 2300 membrane was used as the separator. The electrolyte consisted of a solution of $\mathrm{LiPF}_{6}$ in ethylene carbonate (EC)/dimethyl carbonate (DMC) (1: 1 by volume), $c\left(\mathrm{LiPF}_{6}\right)=1 \mathrm{~mol} \mathrm{~L}^{-1}$. Coin cells were assembled in a dry glove-box filled with high-purity argon. The charge and discharge performance was determined by an automatic NEWARE battery cycler (Neware BTS-610) in a voltage range of $2.5-4.3 \mathrm{~V}$ at room temperature $\left(25 \pm 2{ }^{\circ} \mathrm{C}\right)$.

\section{Results and Discussion}

Table 1 shows the elemental analysis of $\mathrm{FePO}_{4}$ prepared at different temperatures. For both samples, the mole ratio of $\mathrm{P}$ to $\mathrm{Fe}$ is 1.005 , indicating the high purity of the prepared $\mathrm{FePO}_{4}$.

Fig. 1 shows the XRD patterns of the as-prepared $\mathrm{FePO}_{4}$ (Fig. 1a-b) and $\mathrm{LiFePO}_{4}$ (Fig. 1c-d). The XRD patterns of $\mathrm{FePO}_{4}$ indicate $\mathrm{FePO}_{4}$ prepared at $30{ }^{\circ} \mathrm{C}$ (Fig. 1a), and $80^{\circ} \mathrm{C}$ (Fig. 1b) was amorphous and monoclinic, respectively, indicating that treatment temperature had a significant effect on the crystal structure of the as-prepared samples. All the diffraction peaks of $\mathrm{LiFePO}_{4}$ are consistent with the olivine structured $\mathrm{LiFePO}_{4}$, which indicates that the morphology of $\mathrm{FePO}_{4}$ has no significant effect on the structure of $\mathrm{LiFePO}_{4}$.

The SEM images of the as-prepared $\mathrm{FePO}_{4}$ (Fig. 2a-b) and $\mathrm{LiFePO}_{4}$ (Fig. 2c-f) are presented in Fig. 2, from which we can see that the $\mathrm{FePO}_{4}$ precursor prepared at $30{ }^{\circ} \mathrm{C}$ (Fig. 2a) and $80^{\circ} \mathrm{C}$ (Fig. 2b) both show irregular shape, and the porous structure can be seen on their surface, different from the spherical and spheroidal shaped $\mathrm{FePO}_{4}$ reported in literatures, ${ }^{14}$ which may be due to template role played by ethanol. In the ethanol system, ethanol is not only contributory to extraction and crystallization, but also acts as template agent to some extent. Thus, the iron phosphate crystal nuclei form, gradually grow and eventually develop into an irregular porous appearance with the cooperative

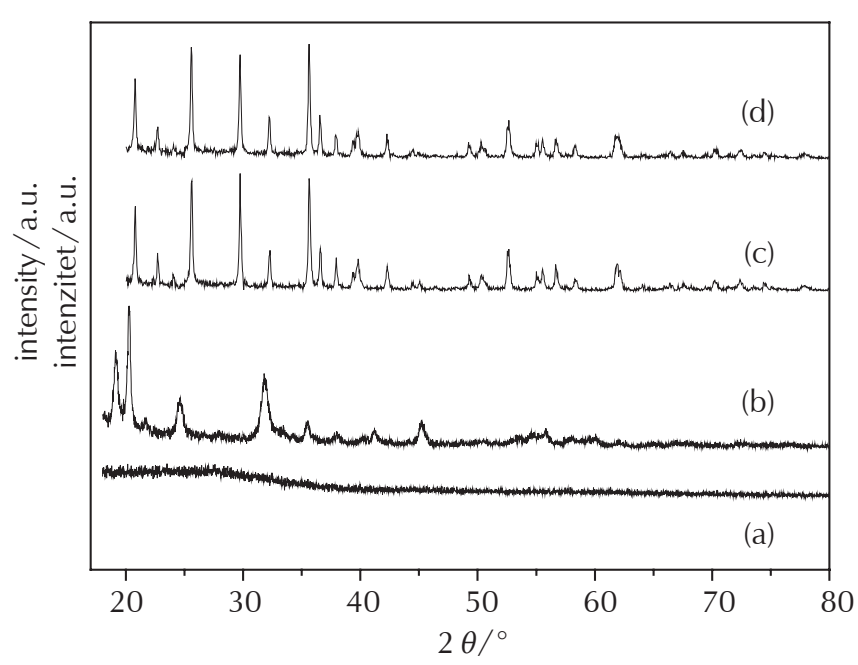

Fig. 1 - XRD spectra of $\mathrm{S} 1 \quad\left(\mathrm{FePO}_{4}\right.$ precursor prepared at $\left.30{ }^{\circ} \mathrm{C}\right)(\mathrm{a}), \mathrm{S} 2\left(\mathrm{FePO}_{4}\right.$ precursor prepared at $\left.80{ }^{\circ} \mathrm{C}\right)(\mathrm{b})$, L1 (prepared from S1) (c), and L2 (prepared from S2) (d) Slika 1 - XRD-spektri S1 (prekursor $\mathrm{FePO}_{4}$ pripravljen pri $30{ }^{\circ} \mathrm{C}$ ) (a), S2 (prekursor $\mathrm{FePO}_{4}$ pripravljen pri $\left.80{ }^{\circ} \mathrm{C}\right)(\mathrm{b})$, L1 (pripravljen iz S1) (c) i L2 (pripravljen iz S2) (d)

effect of $\mathrm{FePO}_{4}$ and $\mathrm{CH}_{3}-\mathrm{CH}_{2}-$ group in ethanol molecules. With close observation, the particle size of $\mathrm{FePO}_{4}$ precursor prepared at $80{ }^{\circ} \mathrm{C}$ is slightly smaller than that prepared at $30^{\circ} \mathrm{C}$. Such result can be explained by the formula of crystal nucleation rate proposed by A. E. Nielsen, and equation of crystal growth rate proposed by Dieksen, etc. ${ }^{15-16}$ According to their research, the crystal nucleation rate is faster at higher temperature, thus, the particle size of $\mathrm{FePO}_{4}$ prepared at $80{ }^{\circ} \mathrm{C}$ is relatively smaller. BET analyses were performed to investigate the specific surface area of the samples. The specific surface area of S2 is $68 \mathrm{~m}^{2} \mathrm{~g}^{-1}$, larger than that of S1 $\left(45 \mathrm{~m}^{2} \mathrm{~g}^{-1}\right)$, which may have an effect on the morphology of the prepared $\mathrm{LiFePO}_{4}$. Fig. 2 (c-d) and Fig. 2 (e-f) show the SEM images of L1 and L2, respectively. As shown in the images, they are all hemispherical hollow. It should be noted that such appearance was firstly synthesized to the best of our knowledge. Obviously, L2 is smaller than L1, the average particle size of $L 2$ is about $1 \mu \mathrm{m}$, while the average particle size of $\mathrm{L} 1$ is about $20 \mu \mathrm{m}$, and the specific surface area of $\mathrm{L} 2\left(15 \mathrm{~m}^{2} \mathrm{~g}^{-1}\right)$ is larger than that of $\mathrm{L} 1\left(10 \mathrm{~m}^{2} \mathrm{~g}^{-1}\right)$, which may indicate the difference between their electrochemical performance.

Table 1 - Elemental analysis of $\mathrm{FePO}_{4}$ prepared at different temperatures (S1: $30{ }^{\circ} \mathrm{C}, \mathrm{S} 2: 80{ }^{\circ} \mathrm{C}$ )

Tablica 1 - Elementna analiza $\mathrm{FePO}_{4}$ pripravljenog pri različitim temperaturama $\left(\mathrm{S} 1: 30{ }^{\circ} \mathrm{C}, \mathrm{S} 2: 80{ }^{\circ} \mathrm{C}\right)$

\begin{tabular}{c|c|c|c|c|c|c|c}
\hline $\begin{array}{c}\text { Sample } \\
\text { Uzorak }\end{array}$ & $w_{\mathrm{Fe}} / \%$ & $w_{\mathrm{P}} / \%$ & $w_{\mathrm{S}} / \%$ & $w_{\mathrm{Ca}} / \%$ & $w_{\mathrm{Mg}} / \%$ & $w_{\mathrm{Si}} / \%$ & $w_{\mathrm{Na}} / \%$ \\
\hline S1 & 29.18 & 16.36 & 0.033 & 0 & 0.022 & 0 & 0.014 \\
S2 & 29.30 & 16.34 & 0.041 & 0 & 0.019 & 0 & 0.023 \\
\hline
\end{tabular}



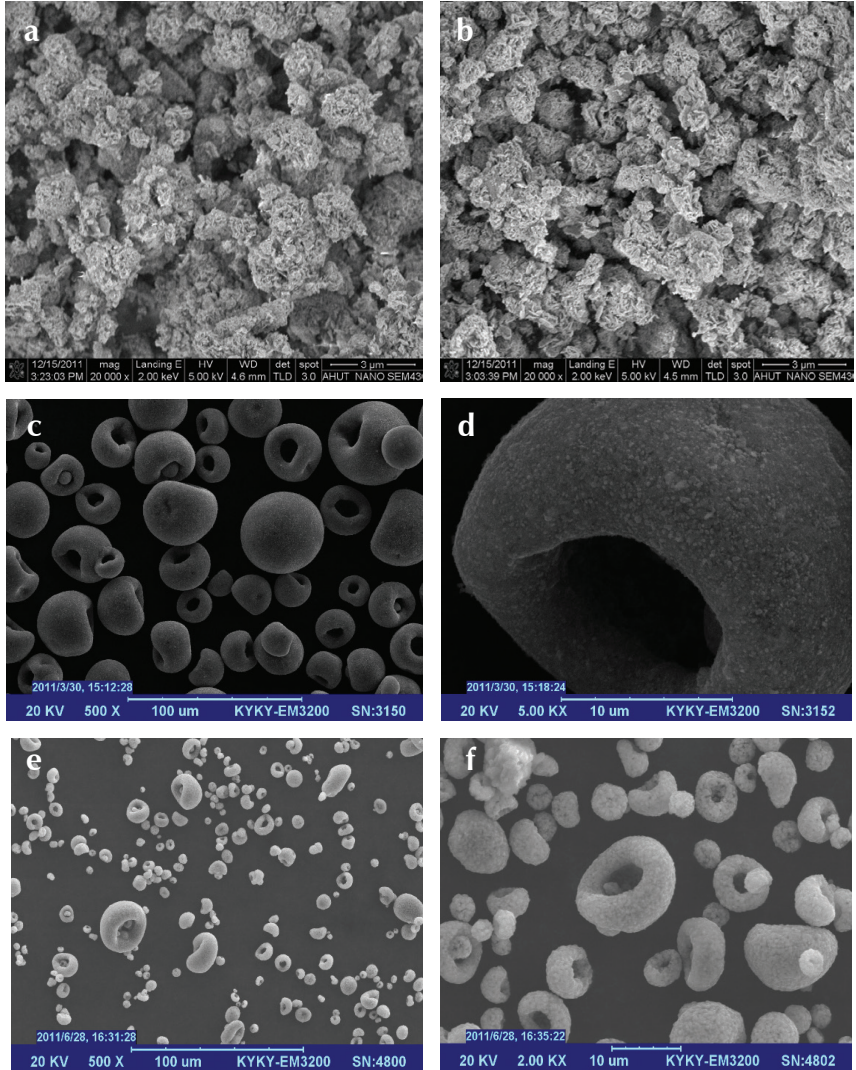

Fig. 2 - SEM images of $\mathrm{S} 1 \quad\left(\mathrm{FePO}_{4}\right.$ precursor prepared at $\left.30{ }^{\circ} \mathrm{C}\right)(\mathrm{a}), \mathrm{S} 2\left(\mathrm{FePO}_{4}\right.$ precursor prepared at $\left.80{ }^{\circ} \mathrm{C}\right)(\mathrm{b})$, L1 (prepared from S1) (c-d), and L2 (prepared from S2) (e-f)

Slika 2 - SEM slike S1 (prekursor $\mathrm{FePO}_{4}$ pripravljen pri $\left.30{ }^{\circ} \mathrm{C}\right)(\mathrm{a})$, $\mathrm{S} 2$ (prekursor $\mathrm{FePO}_{4}$ pripravljen pri $80{ }^{\circ} \mathrm{C}$ ) (b), L1 (pripravljen iz S1) (c-d) i L2 (pripravljen iz S2) (e-f)

Fig. 3 shows the charge and discharge curves and cycling performance of $\mathrm{LiFePO}_{4} / \mathrm{C}$ composite at different rates. As displayed in Fig. 3(A), each charge-discharge curve exhibits a flat and long potential plateau around 3.4 $\mathrm{V}$. The discharge capacities of L1 are $150.7 \mathrm{~mA} \mathrm{~h} \mathrm{~g}^{-1}$ and $135.2 \mathrm{~mA} \mathrm{~h} \mathrm{~g}^{-1}$ at the rates of $0.1 \mathrm{C}$ and $1 \mathrm{C}$, respectively. The discharge capacities of L2 are $155.9 \mathrm{~mA} \mathrm{~h} \mathrm{~g}$ and $141.8 \mathrm{~mA} \mathrm{~h} \mathrm{~g}$ g $^{-1}$ at the rates of $0.1 \mathrm{C}$ and $1 \mathrm{C}$, respectively. Obviously, L2 exhibits better electrochemical performance. Additionally, L2 also demonstrates better cycle stability. After 150 cycles, the capacity retention of $\mathrm{L} 2$ is about $97.8 \%$ and $95.1 \%$ at $0.1 \mathrm{C}$ and $1 \mathrm{C}$, respectively, and the capacity retention of L1 is about $94.6 \%$ and $90.3 \%$ at $0.1 \mathrm{C}$ and $1 \mathrm{C}$, respectively, as illustrated in Fig. 3(B). The better electrochemical performance of L2 can be explained by its smaller particle size. The smaller the particle size is, the smaller is the diffusion resistance of $\mathrm{Li}$ ion. Thus, the utilization of the active materials improves, meanwhile, the volume change caused by the intercalation and extraction behaviour of $\mathrm{Li}$ ion is smaller, which benefits the structural stability, thus a slower capacity decline can be seen.
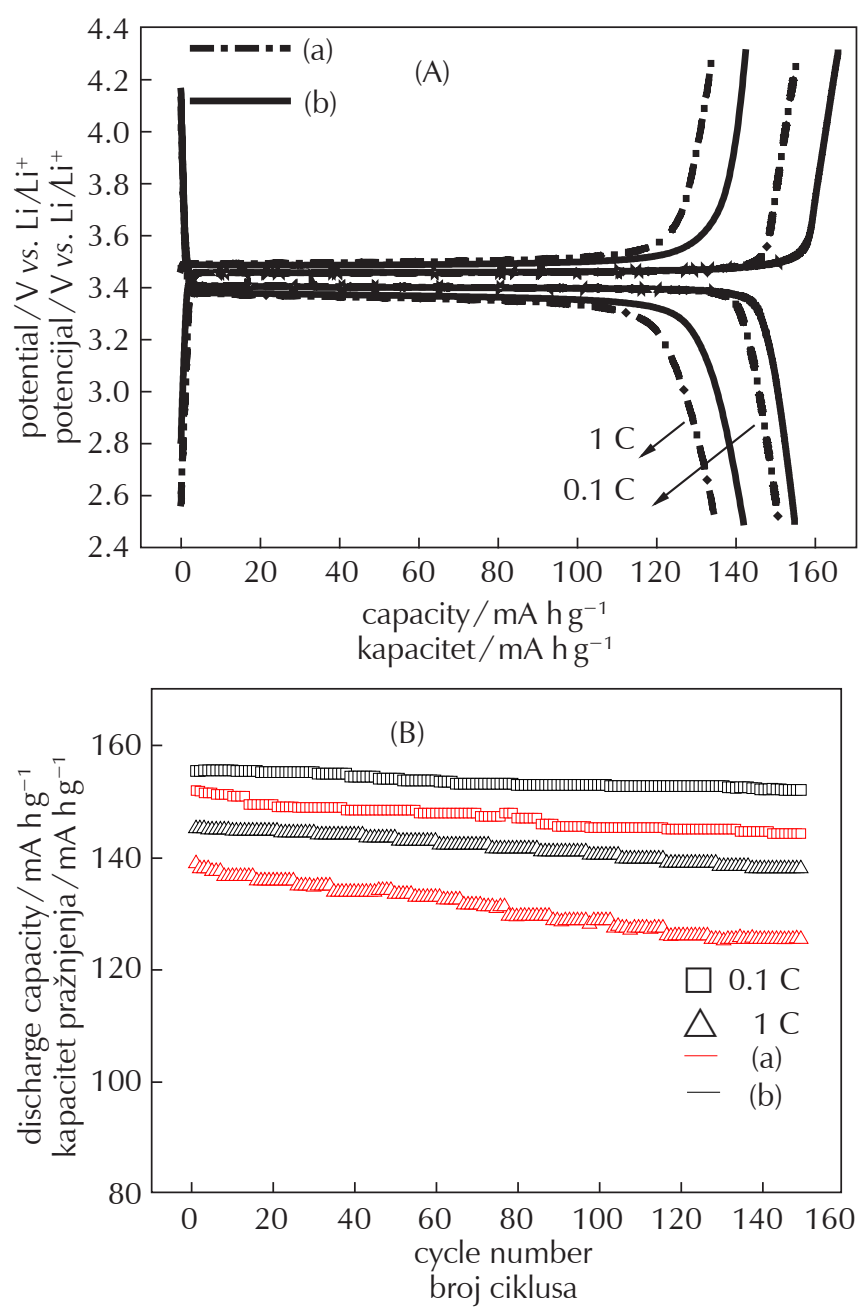

Fig. 3 - Charge-discharge curves of L1 (prepared from S1) (a) and L2 (prepared from S2) (b) at different current rates (A); cycling performances of L1 (prepared from S1) (a) and L2 (prepared from S2) (b) (B)

Slika 3 - Krivulje punjenja i pražnjenja za L1 (pripravljen iz S1) (a) i L2 (pripravljen iz S2) (b) pri različitim brzinama struje (A); ciklička svojstva L1 (pripravljenog iz S1) (a) i L2 (pripravljenog iz S2) (b) (B)

\section{Conclusion}

This work has prepared $\mathrm{FePO}_{4}$ with amorphous and monoclinic crystal form via an interface synthesis method, and studied its effect on the electrochemical performance of $\mathrm{LiFePO}_{4} / \mathrm{C}$. The results showed that $\mathrm{LiFePO}_{4} / \mathrm{C}$ prepared from two precursors were both hemispherical hollow with an olivine crystal structure. $\mathrm{LiFePO}_{4} / \mathrm{C}$ produced from the monoclinic structured precursor exhibited smaller size and better electrochemical performance, and its discharge capacities were $155.9 \mathrm{~mA} \mathrm{~h} \mathrm{~g}^{-1}$ and $141.8 \mathrm{~mA} \mathrm{~h} \mathrm{~g}^{-1}$ at the rates of $0.1 \mathrm{C}$ and $1 \mathrm{C}$, respectively. After 150 cycles, its capacity retention was about $97.8 \%$ and $95.1 \%$ at $0.1 \mathrm{C}$ and $1 \mathrm{C}$, respectively. 


\section{List of abbreviations and symbols \\ Popis kratica i simbola}

\begin{tabular}{|c|c|}
\hline BET & - Brunauer-Emmett-Teller \\
\hline $\mathrm{C}$ & $\begin{array}{l}\text { - a charge or discharge current equal to the capacity } \\
\text { of a battery divided by } 1 \mathrm{~h} \\
\text { - struja punjenja ili pražnjenja jednaka kapacitetu } \\
\text { baterije podijeljenom s } 1 \mathrm{~h}\end{array}$ \\
\hline FE-SEM & $\begin{array}{l}\text { - field-emission scanning electron microscopy } \\
\text { - pretražna elektronska mikroskopija s emisijom polja }\end{array}$ \\
\hline L1 & $\begin{array}{l}\text { - } \mathrm{LiFePO}_{4} / \mathrm{C} \text { composite prepared from S1 } \\
\text { - kompozit LiFePO } / \text { /C pripravljena iz S1 }\end{array}$ \\
\hline L2 & $\begin{array}{l}\text { - } \mathrm{LiFePO}_{4} / \mathrm{C} \text { composite prepared from S2 } \\
\text { - kompozit } \mathrm{LiFePO}_{4} / \mathrm{C} \text { pripravljena iz S2 }\end{array}$ \\
\hline NMP & $\begin{array}{l}\text { - N-methyl-2-pyrrolidone } \\
-N \text {-metil-2-pirolidon }\end{array}$ \\
\hline PVDF & $\begin{array}{l}\text { - poly(vinylidene fluoride) } \\
\text { - poli(viniliden-fluorid) }\end{array}$ \\
\hline S1 & $\begin{array}{l}\text { - FePO } \mathrm{F}_{4} \text { precursor prepared at } 30{ }^{\circ} \mathrm{C} \\
\text { - prekursor } \mathrm{FePO}_{4} \text { pripravljen pri } 30^{\circ} \mathrm{C}\end{array}$ \\
\hline S2 & $\begin{array}{l}\text { - FePO }{ }_{4} \text { precursor prepared at } 80{ }^{\circ} \mathrm{C} \\
\text { - prekursor } \mathrm{FePO}_{4} \text { pripravljen pri } 80{ }^{\circ} \mathrm{C}\end{array}$ \\
\hline XRD & $\begin{array}{l}\text { - X-ray diffraction } \\
\text { - rendgenska difrakcija }\end{array}$ \\
\hline
\end{tabular}

\section{References \\ Literatura}

1. A. K. Padhi, K. S. Nanjundaswamy, J. B. Goodenough, Phospho-olivines as positive-electrode materials for rechargeable lithium batteries, Electrochem. Soc. 144 (1997) 1188-1194, doi: http://dx.doi.org/10.1149/1.1837571.

2. M. Gaberscek, R. Dominko, J. Jamnik, Is small particle size more important than carbon coating? An example study on $\mathrm{LiFePO}_{4}$ cathodes, Electrochem. Commun. 9 (2007) 27782783, doi: http://dx.doi.org/10.1016/j.elecom.2007.09.020.

3. W. M. Chen, L. Qie, L. X. Yuan, Insight into the improvement of rate capability and cyclability in $\mathrm{LiFePO}_{4} /$ polyaniline composite cathode, Electrochimi. Acta 56 (2011) 2689-2695, doi: http://dx.doi.org/10.1016/j.electacta.2010.12.041.

4. C. Delacourt, L. Laffont, R. Bouchet, C. Wurm, J. B. Leriche, M. Morcrette, J. M. Tarascon, C. Masquelier, Toward understanding of electrical limitations (electronic, ionic) in $\mathrm{LiMPO}_{4}(\mathrm{M}=\mathrm{Fe}, \mathrm{Mn})$ electrode materials, J. Electrochem. Soc. 152 (2005) A913-A921, doi: http://dx.doi. org/10.1149/1.1884787.

5. C. S. Sun, Y. Zhang, X. J. Zhang, Z. Zhou, Structural and electrochemical properties of $\mathrm{Cl}$-doped $\mathrm{LiFePO}_{4} / \mathrm{C}$, Power Sourc- es 195 (2010) 3680-3683, doi: http://dx.doi.org/10.1016/j. jpowsour.2009.12.074.

6. X. Z. Liao, Y. S. He, Z. F. Ma, X. M. Zhang, L. Wang, Effects of fluorine-substitution on the electrochemical behavior of $\mathrm{LiFePO}_{4} / \mathrm{C}$ cathode materials, Power Sources 174 (2007) 720-725, doi: http://dx.doi.org/10.1016/j.jpowsour.2007.06.146.

7. Y. H. Huang, K. S. Park, J. B. Goodenough, Improving lithium batteries by tethering carbon-coated $\mathrm{LiFePO}_{4}$ to polypyrrole, Electrochem. Soc. 153 (2006) A2282-A2286, doi: http://dx.doi.org/10.1149/1.2360769.

8. X. K. Guo, Q. Fan, L. Yu, J. Y. Liang, W. X. Ji, L. M. Peng, X. F. Guo, W. P. Ding, Y. F. Chen, Sandwich-like LiFePO 4 graphene hybrid nanosheets: in situ catalytic graphitization and their high-rate performance for lithium ion batteries, J. Mater. Chem. 1 (2013) 11534-11538, doi: http://dx.doi. org/10.1039/c3ta12422c.

9. Y. Wang, K. Otsuka, Oxidation of ethane by reductively activated oxygen over iron phosphate catalyst, J. Catal. 171 (1997) 106-114, doi: http://dx.doi.org/10.1006/ jcat.1997.1803.

10. Y. H. Huang, H. B. Ren, Z. H. Peng, Y. H. Zhou, Synthesis of $\mathrm{LiFePO}_{4} /$ carbon composite from nano- $\mathrm{FePO}_{4}$ by a novel stearic acid assisted rheological phase method, Electrochimi. Acta 55 (2009) 311-315, doi: http://dx.doi.org/10.1016/j. electacta.2009.08.057.

11. J. A. Dirksen, Fundamentals of crystallization: Kinetic effects on particle size distributions and morphology, Chem. Eng. Sci. 46 (1991) 2389-2427, doi: http://dx.doi.org/10.1016/00092509(91)80035-W.

12. Z. C. Shi, Y. X. Li, W. L. Ye, Y. Yang, Mesoporous $\mathrm{FePO}_{4}$ with Enhanced Electrochemical Performance as Cathode Materials of Rechargeable Lithium Batteries, Electrochem. Solid-State Lett. 8 (2005) A396-A399, doi: http://dx.doi. org/10.1149/1.1938852.

13. Y. B. Xua, Y. J. Lua, P. Yin, L. Yan, Z. Y. Yang, R. D. Yang, A versatile method for preparing $\mathrm{FePO}_{4}$ and study on its electrode performance in lithium ion batteries, J. Mater. Process. Tech. 204 (2008) 513-519, doi: http://dx.doi.org/10.1016/j.jmatprotec.2007.12.131

14. L. C. Qian, Y. Xia, W. K. Zhang, H. Huang, Y. P. Gan, H. J. Zeng, $X$. Y. Tao, Electrochemical synthesis of mesoporous $\mathrm{FePO}_{4}$ nanoparticles for fabricating high performance $\mathrm{LiFePO}_{4} / \mathrm{C}$ cathode materials, Micropor. Mesopor. Mater. 152 (2012) 128-133, doi: http://dx.doi.org/10.1016/j.micromeso.2011.11.048.

15. A. E. Nielsen, Kinetics of Precipitation. Oxford: Pergamon Press, 1964, pp. 350-355.

16. J. A. Dirksen, Fundamentals of crystallization: Kinetic effects on particle size distributions and morphology, Chem. Eng. Sci. 46 (1991) 2389-2427, doi: http://dx.doi.org/10.1016/00092509(91)80035-W. 


\section{SAŽETAK \\ Međufazna sinteza $\mathrm{FePO}_{4}$ različitih morfologija i utjecaj morfologije na elektrokemijska svojstva $\mathrm{LiFePO}_{4} / \mathrm{C}$}

Yan-Hua Luo, a,b, Nan He, ${ }^{c}$ Yi-Cun Wang, bei-Guo Cao i Pan Feng a,d

$\mathrm{U}$ ovom je radu korištena metoda međufazne sinteze za pripravu $\mathrm{FePO}_{4}$ različitih morfologija te je istraživan učinak morfologije na pripravu i elektrokemijska svojstva $\mathrm{LiFePO}_{4} / \mathrm{C}$. Rezultati su pokazali da je $\mathrm{FePO}_{4}$ pri temperaturi obrade $30{ }^{\circ} \mathrm{C}$ amorfan, a pri $80{ }^{\circ} \mathrm{C}$ monoklinski. $\mathrm{LiFePO}_{4} / \mathrm{C}$ je pripravljen iz dvaju prekursora oblika polukružne šupljine s kristalnom strukturom olivina. $\mathrm{LiFePO}_{4} / \mathrm{C}$ proizveden iz monoklinski strukturiranog prekursora pokazao je sitniju morfologiju i bolja elektrokemijska svojstva, a njegovi kapaciteti pražnjenja naboja bili su 155,9 mA h $\mathrm{g}^{-1}$ i $141,8 \mathrm{~mA} \mathrm{~h} \mathrm{~g}^{-1}$ pri brzini od $0.1 \mathrm{C}$ i 1 C. Nakon 150 ciklusa, njegov kapacitet zadržavanja je oko $97,8 \%$ i $95,1 \%$ pri 0.1 C i 1 C.

Ključne riječi

$\mathrm{FePO}_{4}, \mathrm{LiFePO}_{4} / \mathrm{C}$, litij-ionska baterija, kompozitni materijali, energija pohrane i pretvorbe

a School of Chemical Engineering; Nanjing University of Science and Technology Jiangsu, 210094 Nanjing, Kina

b Sinosteel Anhui Tianyuan Technology Co., Ltd., 243000 Anhui Maanshan, Kina

c Sinosteel Maanshan Institute of Mining Research Co., Ltd., Maanshan, 243000 Anhui, Kina

d National Quality Supervision and Inspection Center for Industrial Explosive Materials Jiangsu, 210094 Nanjing, Kina
Prethodno priopćenje Prispjelo 17. ožujka 2015. Prihvaćeno 23. svibnja 2015. 